Image and Man - Correlations, eds. Marcin Godawa, Bojan Žalec, Krakow 2020, pp. 79-85.

DOI: http://dx.doi.org/10.15633/9788374386807.07

Anna Jungiewicz

Jagiellonian University in Kraków, Poland

\title{
Metaphor of the World as a Print Press in Early Modern Polish Sermons
}

From the time of first philosophical schools in Athens, a conception of the universe which is built from some hierarchical structured subworlds, two, three or even four, where each one is a reflection of another, higher one, started to function and influence human imagination of the world. In the beginning I would like to recall in short some propositions of such divisions, which are the most important for my thesis, where I would like to highlight some examples of using the metaphor of the world as a printing press in selected texts from the XVII century.

Due to the Pythagorean tradition, the universe was imagined as one, huge, but regular block, which consisted of less geometrical structures (Swieżawski 1980, 370). Plato, as we all remember, is the author of the metaphor of the cave, which illustrates the concept of the reflections of the real, ideal world into the material one. But he also divided the material world into three parts: abovelunar, heavenly/celestial and sublunar. Aristotle developed the division into two parts: above and sublunar; these two worlds were, due to his conception, totally different, also in material meaning, but there can be found some analogies between them. For the European, Christian thought the most important were conceptions of Pythagoras and Plato - the term of triad was Christianized and included in philosophical thoughts of mathematical construction of the world.

Saint Augustine did not make such divisions of the world, but he spoke about four ways in which God reveals Himself. Everyone of them is connected to The Word. The first one is simply Jesus, the second person 
of the Holy Trinity, who was born but not created and was incarnated as a part of the created world. The second ones were the words of Jesus, which he spoke and which are saved in the Gospels. Third ones are the words of the Holy Bible, which describe Jesus and his works. And the fourth ones are the words of the people, witnesses and preachers, who continue, somehow, the mission of Jesus (Domański 1992, 63; Pirovano 1964, 77-104). As we can see, those ways were also put in order from the most important presence of God, the strongest, to the weakest. Moreover, Saint Augustine, as one of the mightiest neoplatonists, expressed beliefs of the eternal presence of ideas in the God's mind, where they exist beyond the time.

Another division was invented by two humanists from the Italian quattrocento: Palingenio and Pico della Mirandola. They divided the world into three parts, similarly to Plato: into abovecelectial, celestial and subcelestial. In Palingenio's Zodiacus vitae the celestial part is nothing but the pure emanation of the eternal light from God: Beyond the frontiers of heaven, as we suppose, does not exist any material body, but there is only pure light, immeasurable, bodiless; the light which the light of our sun is less than, the light which our earthly eyes could not see, the light infinite, which is emanated by God itself (Palingenio 1871, v. 73-79). ${ }^{1}$ Ficino, another Italian neoplatonist, divided the world into four hypostasis: the cosmic mind (mens mundana, intellectus divinus sive Angelicus), the cosmic soul (anima mundana), the natural one and the material one, which is imperfect, bereft of any life, and which endeavors to release itself from any forms (Swieżawski 1980, 161). Those parts were also put in order in the hierarchy, where the truth was transmitted from the higher into the lower ones and where the matter is bad and defiled, and the world is the better, the less dependent on the matter.

The orators and the writers tried to illustrate those divisions with some metaphorical images. One of the most popular of them is a metaphor of the book, where the God is an author, the created world is a text, like in $19^{\text {th }}$ Psalm: „The heavens declare the glory of God; and the firmament sheweth his handywork" and a human is a reader. Ernst Robert Curtius made a bibliographical research and collected lots of examples of such images in the literature from the times of Middle Ages up to Pre-Romanticism

1 All translations in this paper were made by the author. 
(Curtius 2005, 326-333). ${ }^{2}$ But this metaphor was changed due to the fact that the shape of the book was changed as well. So firstly the metaphor was leaning on a roll, secondly, on the manuscript codex and, at last, on the printed book, which is the main theme of my thesis. The Poet Francis Quarles has mentioned it in one of his Emblems from 1635:

The world's a book in folio, printed all

With God's great works in letters capital:

Each creature is a page; and each effect

A fair character, void of all defect. ${ }^{3}$

The vision of the world as a perfectly printed book is one of the most optimistic ones; another one reserved the privilege of perfection to St Mary only.

First of my examples was introduced by Joannes Amos Komensky, a Czech Protestant scholar, an author of many pedagogical works. His pansofian philosophy was founded on Plotinus' belief that the world is derived from God and that the world is ingrained in God and consists of some layers: material, possibilities, ideal models, minds and moral ones. He was not only interested in how the world is built, but, how we get to know, how the learning is possible. So his question was more about epistemology than the ontology. In the work Typographeum vivum (1657) he compared the process of learning to the art of printing. He started with describing the process of the thought. Firstly, God wanted to reveal Himself, by creating the material world. Secondly, God's creations, having minds, are able to look at the world and admire it, so that the wisdom is impressed in their minds. Thirdly, the wisdom impressed in minds can be expressed outside with the sounds of a speech. Later on, the speech can be changed into the signs of the text, of the books, which help them to last longer. Next, while reading books, the wisdom which is contained in them, is impressed in another minds again and again, more widely and more intensively, and at

2 In the section dedicated to the Book of the Nature author recalled examples from the works of Alen de Lille, Thomas a Kempis, Lodovico from the Granada, Hugo of St. Victor, Hugo of Folieto, Bernard Silvestris, John of Salisbury, St Bonaventure, Konrad of Megenberg, Nicolaus Cusanus, Paracelsus, Michel de Montaigne, Descartes, Francis Bacon, Campanella, John Owen, Thomas Browne, Francis Quarles, Donne, Milton, Vaughan, Herbert, Crashaw, Galileo, John Swammerdam, Boerhaave, Diderot, Voltaire, Rousseau, Edward Young, Robert Wood, brothers Grimm up to Goethe.

3 Cited by: Curtius 2005, 330. 
last in the mind of a human the image of the God, who is the archetype of all, is impressed. But Komensky was also an author of the idea of the learning improvement. He believed that there is a possibility to organize the system of the education along the lines of the printing press. Like the paper put into the printing machine is fulfilled with the text, the mind of the pupil would be fulfilled with the wisdom, if some conditions would be made. In traditional typography, there are three main workers and three helpers needed. The main work is made by a typesetter, who puts fonts into the right order, a corrector, who checks if the text is set properly, and a printer, who puts the pattern into a printing press and make some copies. Three people help them: a lector, who reads the text for the corrector, so that he could compare the copy and the original version, and two workers who apply the paint and remove it from the form. Analogically, in the learning process, Komensky saw some tasks for three main workers and for three helpers. Main workers are: an educator, who prepares texts and handbooks, a scholar, who does some corrections of those handbooks, and the teacher, who has to transmit this wisdom from the paper into the pupils' minds. Helpers are pastors/ministers, parents and some more ambitious pupils, who had to be like managers for the others (Komeński 1964, 535-542). Komensky did not take into consideration the free will of pupils. They were actually like a sheet of paper, which just takes all impressions, during the process of education, bringing up. Of course, there were some differences in skills, in capability of learning between some pupils, but Komensky presumed that all of them will have a good will to learn. Every capable pupil, properly trained will be a walking library. What is important, the main goal was not just to put the right impressions into the pupils' minds, but to shape the whole humanity along the lines of God. Actually, the main goal was to impress, or print, the image of God into the minds of humans.

The second example of the metaphor of the world as the printing press comes from the collection of the sermons by Fabian Birkowski, a Polish preacher from the Dominican convent. In 1620 he wrote the introduction to this collection, where he divided the world into four parts: archetypical, archetypus, angelic angelicus, elemental and microcosmical microcosmos$u m$. The first one, archetypical, is the model of every other world, like in the poem of Boetius: Mundum mente gerens pulchrum pulcherrimus ipse which could be translated: The prettiest from the prettiest world forms the images in his image.) The second world, angelicus, is enlightened directly by 
God, without any mediation, as in the quotation of Birkowski: "Like a big card put into the printing press is covered with a wise text immediately, one by one, in the same way the knowledge of the angels is poured into their minds strictly from the act of creation, and is impressed there, or, so to speak, is printed there." The third world is the material one, where all creatures live and move, enlightened by the light of God, not directly, but with the sun. As Birkowski puts it: "This sunlight exemplifies the invisible one, which enlightens our souls and which comes from the sun of the Justice." And the fourth world is the world of each human mind and soul, which is enlightened with this light from God. This conception is metaphysical, not an astronomical or geographical. Those four worlds are put into order from the most to the least enlightened. This belief has great consequences in all of Fabian Birkowski's works. He was a master of using metaphors and he illustrated all truths and dogmas with metaphorical images. For example, the main thesis of the sermon for the 22nd Sunday after the Pentecost is that we should prepare our hearts as a home for God. Later on he described part by part this home, expressing what every part means, like the foundation, walls, roof. He used metaphors or allegories frequently, but not only because they're interesting rhetorical ornaments, but because he believed that the world is built figuratively, so the best way to explain it, is with using figures like metaphors.

The last example of the metaphorical use of the printing press comes from the sermon of Franciszek Rychłowski, a Polish preacher, from 1667, and was written for the celebration of the Immaculate Conception of the Saint Mary (Rychłowski 2012, 159-183). The whole sermon is dedicated to the explication of the metaphor of the Mary as the greatest book ever. But before Rychłowski started to explain it, he presented the reasons of such a comparison. He remembered Sint Thoms from Aquina's division of causes. God is the prime cause, but he created also secondary causes, causas secundis, which have some power from him and can work and influence the created world. Due to this idea, holy Mary is the most precious book, the most precious creature, because she was created directly by God, before the other ones, as the Wisdom of God. The preacher talks about two editions of this book. The first took place in the heavenly printing press, before all the ages, in God's mind. The second edition took place in time, during conception of Saint Anna. Rychłowski said that this edition was not emendata. What does it mean? The dream of early modern editors was to make an edition 
called emendata. The texts which they disposed, were often contaminated, distorted by copyists and incomplete. They dreamed about discovering the original text and corrected it from all mistakes. In case of Saint Mary there was no need to do any corrections, because she was perfect and - immaculate. Next point is an approbation. Despite of the fact, that Saint Mary did not need any approbations, she had some of them. She was mentioned and approved in some works by Muhammad, Luther and Erasmus. The book had also some dedications and offertory letters - saint Mary was dedicated and offered completely to God. Actually, not only the person of the saint Mary is the subject of the metaphore, but also her Immaculate Conception, which is illustrated by perfectly correct edition.

Going towards the end of my presentation, I should ask about the function of those metaphors. It's far more than only a rhetorical ornament, because it illustrates some philosophical truths. First, the thought of figurative construction of the world, which is built from the different, hierarchical parts. But it illustrates not only the construction of the world, but especially, also the transmission of the truth and the knowledge. So the function is rather epistemological, than ontological. Secondly, it illustrates the preexistence of creatures in God's mind before the act of creation. And thirdly, it indicates human's need to shape their own image according to God's image, which is possible thanks to the image of God existing in the nature.

\section{REFERENCES}

Barasch M. (1991), Imago hominis. Studies in the language of art, Vienna.

Curtius E. R. (2005), Literatura europejska i łacińskie średniowiecze, transl. A. Borowski, Kraków.

Domański J. (1992), Tekst jako uobecnienie. Szkic z dziejów myśli o piśmie i książce, Warszawa.

Gorzkowski A. (2001), “Ut pictura verba...” Zagadnienie unaocznienia w retoryce starożytnej i wczesnonowożytnej, "Pamiętnik Literacki” 2, pp. 37-59.

Komeński J. A., Suchodolski B. (red.) (1964), Pisma wybrane, transl. K. Romer, WrocławWarszawa-Kraków-Gdańsk.

Kristeller O. (1961), Renaissance Thought: The Classic, Scholastic and Humanist Starins, New York.

Bielak A., Stępień P. (red.) (2013), "Ut pictura poesis, ut poesis pictura”. O związkach literatury i sztuk wizualnych od XVI do XVIII wieku, Warszawa.

Skwara M., Wysłouch S. (red.) (2006), "Ut pictura poesis", Gdańsk. 
Palingenio M., Wiese Ch. H. (ed.) (1871), Zodiacus Vitae sive de hominis vita libri XII, Leipzig.

Pelc J. (1973), Obraz-słowo-znak. Studium o emblematach $w$ literaturze staropolskiej, Wrocław-Warszawa-Kraków-Gdańsk.

Pirovano D. (1964), La parola di Dio come 'Incarnazione' del Verbo in saint Agostino, "Augustinianum" 4, pp. 77-104.

Rychłowski F., Pawlak W., Niebielska-Rajca B. (red.) (2012), Na dzień Niepokalanego Poczęcia Panny Przenaświętszej kazanie wtóre (1667), in: "Umysł stateczny i w cnotach gruntoswny". Prace edytorskie dedykowane pamięci Profesora Adama Karpińskiego, red. R. Grześkowiak, R. Krzywy, Warszawa, pp. 159-183.

Swieżawski S. (1980), Dzieje filozofii europejskiej w XV w., t. 5, Warszawa. 
